opinion about whether pneumoconiosis causes or materially accelerates death the doctors of the panels study the pathologist's report and examine the relevant organs. They also consider the terminal illness and the mode of death, which are available in most cases. Furthermore, they usually have a record of the deceased's health over many years. They are thus able to judge the presence of chronic bronchitis and its influence on the cause of death. There are no other physicians in the country who possess the panels' unique experience and opportunity of comparing their findings during life with the appearance of the lungs after death. This experience is based on about 20,000 clinical examinations and 4,000 postmortem examinations annually. The panels have requested that the lungs be perfused before examination, and the Association of Clinical Pathologists issued a leaflet in 1971 advising this and its recommendation was endorsed by the Brodrick Committee. ${ }^{24}$ Differences of opinion between the coroners' pathologists and the panels are not frequent.

Dr. Davies's attitude to the panel is somewhat ambivalent, for while conceding that membership of it can bring enormous experience of the pathology of pneumoconiosis he criticizes panel members for lack of experience. The doctors of the panels are not expected to become competent pathologists overnight. When newly appointed they examine necropsy material with an experienced colleague, often in the presence of the pathologist, and thus become familiar with the morbid anatomy of the pneumoconioses. Opinion on the cause of death is given not by one but by two doctors. We acknowledge the debt of gratitude owed to our colleagues in the N.H.S., especially to pathologists, chest physicians, and others who, in general, appreciated that the panel doctors are clinicians who have a difficult job to do under circumstances which are sometimes ill-understood and misrepresented.-We are, etc.

R. M. MCGowaN

W. RAYMOND PARKES T. J. G. PHILLIPS

R. G. B. WILLIAMSON

Department of Health and Social Security, John Adam Street, 1 Kibelstis, J. A., et al., American Review of

Morgan, W. K. C., et al., Annals of the New Morgan, W. K. C., et al., Annals of the
York Academy of Sciences, 1972, 200, 252.

Gilson. Academy of Procedings of the Royal Society of Medicine, 1970, 63, 857.

Higgins, I. T. T., Annals of the New York Academy of Sciences, 1972, 200, 197.

Medical Research Council Special Committee. British Medical fournal, 1966, 1, 101 .

6 Ulmer, $W$. T., in Pneumoconiosis. Proceedings of the International Conference, ed. $\mathrm{H}$. A. Shapiro p. 328. Cape Town, Oxford University Press,
1970. 7 Ulmer, W. T., and Reichel, G., Annals of the New York Academy of Sciences, 1972 , 200, 211. 1962, 19. 171.

Caswell, C. Bergmann, I, and Rossiter, C. E. in Inhaled Particles III, ed. W. H. Walton,

10 R. 713. Woking. Unwin, 1971. 1960, 17, 87.

11 Rossiter, C. E.. Transactions of the Society for Occupation Medicine, 1972, 22, 83.

Reichel. G., and Ulmer, $w$. T., in Inhaled Particles III, ed. W. H. Walton, p. 897. Woking, 13 Lippmann, M., Albert, R. E., and Peterson, Walton, p. 105. Woking, Unwin, 1971 .

14 Albert, R. E., Wippmann, M., and Peterson, H. T,. jun., in Inhaled Particles III, ed W. $\mathrm{H}$. Walton, p. 165. Woking, Unwin, 1971 .

15 Sanchis, J., et al., in Inhaled Particles III, ed. W. H. Walton, p. 183. Woking, Unwin, 1971 Morgan W. K. C., et al., Arthe
mental Health, 1974, 28, 182 .
17 Rogan, J. M., British fournal of Industrial Medicine, 1973, 30, 217

E. T., British. Coumal of Lap, N. L., and Morgan, E. J., British.

19 Kibelstis, J. A., Chest, 1973, 63, 501.

20 Lavenne, F., in Pneumoconiosis. Proceedings of the International Conference, ed. E. H. Shapiro, p. 521. Cape Town, Oxford University Press, 1970.

21 Morgan, W. K. C., Lapp, N. L., and Seaton, A., Fournal of Occupational Medicine, 1972, 14, 839 . mandus, H. E., Fournal of Occupational Medicine, 1974, 16, 245.

3 Lapp, N. L., et al., Lancet, 1974, 1, 351.

Cerrification Report of the Committee on Death Certification and
H.M.S.O., 1971.

\section{Propranolol in the Treatment of Migraine}

SIR,-The paper, "Propranolol in the Treatment of Migraine," by Drs. T-E. Widerøe and T. Vigander (29 June, p. 699) prompts me to report two patients in whom I suspect propranolol to be a precipitating factor of classical migraine.

Both patients were receiving the drug for the treatment of hypertrophic obstructive cardiomyopathy. The first, a boy of 19, started propranolol $40 \mathrm{mg}$ three times a day in March 1972 and two weeks after the dose was increased to $80 \mathrm{mg}$ three times a day he developed classical migraine for the first time. Clonidine $50 \mu \mathrm{g}$ daily reduced the frequency and severity of attacks, though they persist. The second patient, a woman of 48, similarly had never previously experienced migraine and there was no family history of the disorder. She started propranolol $10 \mathrm{mg}$ four times a day in February 1972 and this was increased by stages to $80 \mathrm{mg}$ three times a day in June 1973. In April 1974 she presented after four episodes of vascular headache associated with teichopsia and left-sided sensory disturbance. Clinical examination, E.E.G., and brain scan were normal and she has had no further symptoms following the exhibition of clonidine $25 \mu \mathrm{g}$ twice daily.

Eight patients with hypertrophic obstructive cardiomyopathy on propranolol attend the clinic. A much larger group with

TABLE I

\begin{tabular}{|c|c|c|c|c|c|c|c|c|c|}
\hline & & & & \multicolumn{3}{|c|}{ Smokers } & \multicolumn{3}{|c|}{ Non-smokers } \\
\hline & & & & Total & $\begin{array}{l}\text { Leg Vein } \\
\text { Thrombosis }\end{array}$ & $\%$ & Total & $\begin{array}{l}\text { Leg Vein } \\
\text { Thrombosis }\end{array}$ & $\%$ \\
\hline Control & .. & .. & .. & 33 & 12 & $36 \cdot 4$ & 55 & 24 & 43.6 \\
\hline Calciparine & .. & .. & .. & 24 & 4 & 16.7 & 36 & 2 & $5 \cdot 6$ \\
\hline Stimulator .. & .. & .. & .. & 21 & 7 & 33.3 & 34 & 12 & $35 \cdot 3$ \\
\hline & & To & & 78 & 23 & $29 \cdot 5$ & 125 & 38 & $30 \cdot 4$ \\
\hline
\end{tabular}

TABLE II

\begin{tabular}{|c|c|c|c|c|c|c|c|c|c|}
\hline & & & & \multicolumn{3}{|c|}{ Smokers } & \multicolumn{3}{|c|}{ Non-smokers } \\
\hline & & & & Total & $\begin{array}{c}\text { Leg Vein } \\
\text { Thrombosis }\end{array}$ & $\%$ & Total & \begin{tabular}{|c|} 
Leg Vein \\
Thrombosis
\end{tabular} & $\%$ \\
\hline $\begin{array}{l}\text { Acute } \\
\text { Control .. }\end{array}$ &.. & .. & .. & 2 & 1 & $50 \cdot 0$ & 8 & 4 & $50 \cdot 0$ \\
\hline Calciparine &.. &. &. & 3 & 0 & 0 & 0 & 0 & 0 \\
\hline \multirow[t]{2}{*}{ Stimulator } & .. & . &.. & 3 & 1 & 33.3 & 3 & 2 & 66.7 \\
\hline & \multicolumn{3}{|c|}{ Total } & 8 & 2 & $25 \cdot 0$ & 11 & 6 & $54 \cdot 5$ \\
\hline $\begin{array}{l}\text { Non-acute } \\
\text { Control }\end{array}$ & .. & .. & .. & 31 & 11 & 35.5 & 47 & 20 & 42.5 \\
\hline Calciparine & .. &.. & .. & 21 & 4 & 19.0 & 36 & 2 & $5 \cdot 6$ \\
\hline Stimulator & .. &.. &.. & 18 & 6 & 33.3 & 31 & 10 & $32 \cdot 3$ \\
\hline & & Total & & 70 & 21 & 30.0 & 114 & 32 & $28 \cdot 1$ \\
\hline
\end{tabular}

ischaemic heart disease and arrhythmias are on beta-blocking drugs-mostly practolol or oxprenolol-and I am not aware of migraine presenting for the first time in this group. - I am, etc.

Cardiac Department,

C. J. SHARPE Western

\section{Smoking and Venous Thrombosis}

SIR,-The papers by Dr. A. J. Handley and Mr. D. Teather (27 July, p. 230) and by Dr. P. Marks and Dr. P. A. Emerson (p. 232) show that non-smokers have a significantly higher incidence of venous thrombosis in the legs after myocardial infarction than smokers.

We have studied the prophylaxis of legvein thrombosis in 203 patients who underwent major surgery, were monitored by the ${ }^{125}$ I uptake test, and whose smoking history was recorded. The original purpose of this trial was to compare a group on low-dose subcutaneous heparin, another receiving electrical calf-muscle stimulation, and a control group. The trial will be reported fully elsewhere. show no significant difference in the incidence of postoperative leg-vein thrombosis between smokers and non-smokers (see table I). Only 19, however, were operated on as emergencies, and probably the status of a patient who has had a myocardial infarct may be likened to that of a patient operated on for an acute illness rather than as an elective procedure. In the 19 emergency operations there was a higher incidence of postoperative leg vein thrombosis among non-smokers (see table II). The figures are, of course, too small for statistical analysis, but if the series were extended the difference might well become significant.-I am, etc.,

\section{Scarborough Hospital,}

A. V. POLLOCK
The overall results in these 203 patients 